\title{
$\beta$-carotene and retinol contents in the meat of herbivorous ungulates with a special reference to their public health importance
}

\author{
Wageh Sobhy DARWISH ${ }^{1,2)}$, Yoshinori IKENAKA ${ }^{1,3) *}$, Alaa Eldin MORSHDY2), Kamal Ibrahim ELDESOKY ${ }^{4)}$, \\ Shouta NAKAYAMA ${ }^{1)}$, Hazuki MIZUKAWA ${ }^{1)}$ and Mayumi ISHIZUKA ${ }^{1)}$ \\ ${ }^{1)}$ Laboratory of Toxicology, Department of Environmental Veterinary Sciences, Graduate School of Veterinary Medicine, Hokkaido \\ University, Sapporo 060-0818, Japan \\ ${ }^{2)}$ Food Control Department, Faculty of Veterinary Medicine, Zagazig University, Zagazig, Egypt \\ 3) Water Research Group, Unit for Environmental Sciences and Management, North-West University, Potchefstroom, South Africa \\ 4)Educational Animal Hospital, Faculty of Veterinary Medicine, Zagazig University, Zagazig 44510, Egypt
}

(Received 14 May 2015/Accepted 6 October 2015/Published online in J-STAGE 24 October 2015)

ABSTRACT. The aim of this study was to estimate total carotenoids, $\beta$-carotene and retinol concentrations in the livers and muscles of some ungulates (cattle, buffalo, sheep, goats and horses) in comparison with the Wistar rats as a control. Cattle and horses had the highest contents of total carotenoids and $\beta$-carotene. Unexpectedly, sheep was the highest accumulator of retinol with a mean concentration of $203 \pm 23.34$ $\mu \mathrm{g} / \mathrm{g}$, while the least accumulator was buffalo, having a mean value of $58.28 \pm 13.77 \mu \mathrm{g} / \mathrm{g}$. Livers had higher contents of the examined phytochemicals than muscles. Consumption of these tissues may provide human with some needs from these important phytochemicals, though ingestion of livers, especially that of the sheep, is not advisable for the pregnant women.

KEY WORDS: carotenoid, retinol, ungulate

doi: 10.1292/jvms.15-0287; J. Vet. Med. Sci. 78(2): 351-354, 2016

Carotenoids are a family of phytochemical compounds that are synthesized naturally by higher plants. Carotenoid metabolism mainly takes place at the liver of animals and human. Meat-producing animals reared on high forage rations pass a portion of the ingested carotenoids into the milk, muscle and body fat [5].

Carotenes (mainly $\beta$-carotene) are precursors of retinol (Vitamin A), a critical fat-soluble vitamin, which is important for cell division and cell differentiation, normal vision, bone growth and reproduction [17]. Specifically, it is responsible for maintaining the surface lining of the eyes and the lining of the respiratory, urinary and intestinal tracts. The integrity of the skin and mucous membranes is maintained by retinol, creating a biodefense barrier to bacteria and viruses [13, 18]. In addition, retinol is involved in the regulation of immune function by supporting the production and function of white blood cells $[2,15]$.

Retinol is an essential dietary substance, which is required for rhodopsin formation and vision [3, 4]. It is estimated that 250 million persons are marginally deficient in vitamin A [22]. The exact number of persons who consume vitamin A well in excess of physiological needs is unknown, especially in developing countries. This number is clearly high, espe-

*Correspondence to: Ikenaka, Y., Laboratory of Toxicology, Department of Environmental Veterinary Sciences, Graduate School of Veterinary Medicine, Hokkaido University, Sapporo-shi, Kitaku, Kita 18, Nishi 9, Sapporo 060-0818, Japan.

e-mail:y_ikenaka@vetmed.hokudai.ac.jp

(C)2016 The Japanese Society of Veterinary Science

This is an open-access article distributed under the terms of the Creative Commons Attribution Non-Commercial No Derivatives (by-nc-nd) License $<$ http://creativecommons.org/licenses/by-nc-nd/3.0/>. cially in economically developed countries, in which fortified foods and nutritional supplements containing preformed vitamin A are widely available [22]. At the same time, higher oral doses of vitamin A have been shown to be teratogenic, and accordingly, the World Health Organization has recommended that the daily intake for pregnant women should not exceed $3.3 \mathrm{mg} /$ day $[12,22]$. Thus, not surprisingly, both a deficiency and excess of retinol adversely affect human and animal health.

The contents of carotenoids in the fat and milk had been extensively studied in cattle. However, there is little information available about the content of these naturally occurring phytochemicals in livers and muscles of other meat-producing animals like buffalo, sheep, goat and horses. Additionally, the contribution of the relevant concentrations of these phytochemicals in the meat (muscle and liver) to human health is poorly studied. Thus, this investigation was undertaken to estimate the concentrations of $\beta$-carotene (a major carotenoid), retinol (a major retinoid) and total carotenoids in the livers and muscles of some meat-producing animals (cattle, buffalo, sheep, goat and horses). The rat was used as a control animal in this study. Additionally, $\beta$-carotene, total carotenoids and retinol contents were measured in the livers and muscles of both grass and grain-fed beef using a high performance liquid chromatography. Furthermore, the estimated daily intake of these phytochemicals was calculated and discussed with their relevant public health importance.

All experiments using animals were performed according to the guidelines of Zagazig University and Hokkaido University Institutional Animal Care and Use Committee.

Liver and muscles are the major carcass parts consumed by the Egyptian population, so liver and muscle samples (Longissimus dorsi muscles) were collected from 125 adult 
males, 20 each of buffalo, horses, sheep and goats (all tested animals were living under green ration receiving either green berseem clover or lucerne with $\beta$-carotene content of 150 $235 \mathrm{mg} / \mathrm{kg}$ [14]). Five rats were used as control animals. In case of cattle only, samples were collected from 40 individuals (20 each of grass-fed and grain-fed animals). Samples from cattle (Bos taurus) and buffalo (Bubalus bubalis) between the ages of two and five years $(3.67 \pm 0.58$ years old) and ( $3.17 \pm 0.78$ years old) for both animal species, respectively, were collected from Zagazig city abattoir directly after slaughter. Samples from thoroughbred horses (Equus caballus) between the ages of four and six years (5.33 \pm 1.15 years old) were generous donations from JRA (Japan Racing Association, Tokyo, Japan). Goats (Cipra hircus) and sheep (Ovis aries) samples were collected from local farms at Hokkaido, Japan, and sacrificed at Hokkaido University. The ages of the goats and sheep were $2.03 \pm 0.95$ and $1.87 \pm$ 0.65 years old, respectively. The samples were collected in the period of March 2011 to September 2011. The exported samples from Egypt to Japan were shipped frozen in plastic falcon tubes ( $20 \mathrm{~g}$ sample in $50 \mathrm{~m} l$ capacity tube) after getting the required permissions from Egyptian and Japanese authorities. Nine-week-old Wistar male rats (SLC, Hamamatsu, Japan) were housed at $24 \pm 1^{\circ} \mathrm{C}$ with $12 \mathrm{hr}$ light and $12 \mathrm{hr}$ dark cycles, and given laboratory feed and water $\mathrm{ad}$ libitum. Rats were anesthetized and sacrificed with carbon dioxide. The rat tissues, used as controls in this study, were removed and perfused with cold $1.15 \%$ potassium chloride which removed the blood.

Beta-carotene and retinol standards were purchased from Sigma Chemical (St. Louis, MO, U.S.A.). All other reagents were of analytical grade or the highest quality available and purchased from Wako Pure Chemical Industries (Tokyo, Japan).

Total carotenoids were extracted from the livers and muscle of the examined animals and measured according to the previously described method [20].

Beta-carotene and retinol were extracted from the liver and muscle of each animal according to the method described previously [11]. $\beta$-carotene and retinol were identified by using standards from Sigma Chemical. The quantification was performed using calibration curves of standard solutions. Measurements were repeated at least twice for each sample.

The Estimated Daily Intake (EDI) of carotenoids and retinoids was calculated based on integration of data from analysis of carotenoids and meat consumption rates by Egyptian adults.

EDI (mg/adult person) for $\beta$-carotene, total carotenoids and retinol, was obtained using the following equation described by WHO [21]:

$\mathrm{EDI}=\mathrm{C} \times \mathrm{M}_{\mathrm{IR}} \times 10^{-3}$

Where $\mathrm{C}$ is the concentration of the carotenoid $(\mu \mathrm{g} / \mathrm{g})$; $\mathrm{M}_{\mathrm{IR}}$ is the meat ingestion rate in Egypt, which was estimated at $85.7 \mathrm{~g} /$ day/adult [10].

All data are expressed as mean \pm standard deviation (SD). Statistical significances were evaluated by Tukey's Kramer HSD difference test using JMP (SAS Institute, Cary, NC, U.S.A.). $P<0.05$ was considered to be significant.
Beta-carotene and retinol are the major carotenoid and retinoid found in our food of animal origin. The observed concentrations of $\beta$-carotene in the muscles of examined ungulates ranged from 0.11 to 0.73 , while in the liver samples, this range was from 2.91 to $6.96 \mu \mathrm{g} / \mathrm{g}$, indicating that muscles contained lower concentrations (about one-tenth) of $\beta$-carotene in comparison to the contents in the liver. Grassfed cattle and horse samples had the highest concentrations of $\beta$-carotene followed by buffalo, goats and sheep, respectively. Rats, which are used as a control laboratory animal in this study, were shown to be non-accumulator of $\beta$-carotene (Fig. 1). The higher concentrations of $\beta$-carotene in the liver compared with the muscle in the cattle are in agreement with a previous report by Yang et al. [19].

Concerning the total carotenoid contents in the tissues of the examined animals, the values follow the same trend as the $\beta$-carotene contents in these tissues. Muscle had lower concentrations compared with the liver (Fig. 2). Cattle and horse had the highest content of carotenoids in both examined tissues followed by buffalo and finally sheep and goats. Rats had very low concentrations compared with ungulates, which indicates that rodents have a different behavior in the accumulation of carotenoids. The concentrations of total carotenoids in the livers ranged from $0.92 \pm 0.17 \mu \mathrm{g} / \mathrm{g}$ to $7.66 \pm 0.27 \mu \mathrm{g} / \mathrm{g}$ in the examined samples (Fig. 2).

As $\beta$-carotene is rapidly converted to retinol in the livers of many animal species, so we measured retinol contents in the livers and muscle of the examined animals. In contrast to carotenoid profile, sheep, just like rats, had a high content of retinol with the least value obtained in goats. This may indicate that all of the $\beta$-carotene was converted into retinol in the case of rats. Especially, that rat diet contained wheat, corn, soyabean and fish oil with $\beta$-carotene content of $2.5 \%$ in contrast to ungulates, which received only a grass diet like berseem clover and lucerne containing $\beta$-carotene concentrations of 0.15 to $0.23 \%$ [14].

Like in case of carotenoids, muscle had lower contents of retinol in comparison to livers. The observed concentrations of retinol were highest in the liver of the rats $(234.26$ $\pm 18.99 \mu \mathrm{g} / \mathrm{g})$ and lowest in buffalo $(58.28 \pm 13.77 \mu \mathrm{g} / \mathrm{g})$ (Fig. 3). These results were in agreement with our previous report, that rat had the highest content of retinol in the liver compared with deer, cattle and horse [6].

Cattle produced under extensive grass-based production systems generally have carcass fat, which is more yellow than their concentrate fed counterparts, which may be as a result of the carotenoids intake from the lush green forages [5]. In this investigation, we studied the effects of grass and grain feeding on carotenoid and retinoid contents in the cattle. We observed that grass-fed steers incorporated significantly higher amounts (5- to 7-fold) of $\beta$-carotene, total carotenoids and retinol in liver and meat as compared to grain-fed animals (Figs. 1-3), presumably, due to the high $\beta$-carotene content of fresh grasses as compared to cereal grains [7]. The same pattern of difference in $\beta$-carotene content between grass- and grain-fed cattle was also observed in Australian and Argentine cattle [5, 8, 19]. The straindifferences between the Egyptian (this study), Australian 


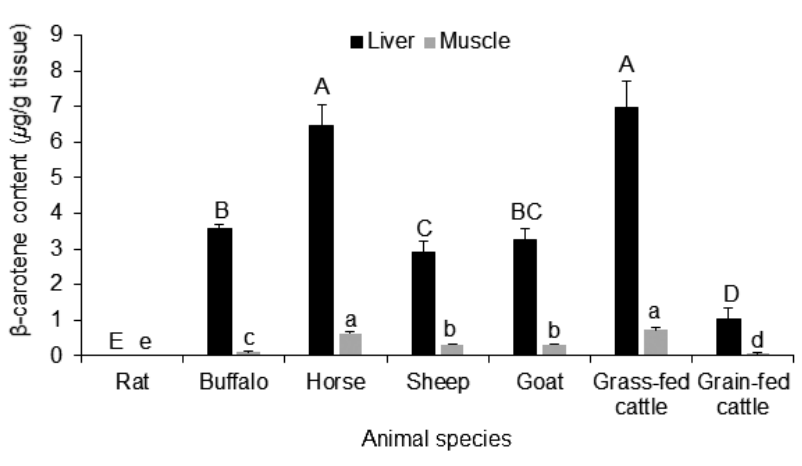

Fig. 1. $\beta$-carotene content $(\mu \mathrm{g} / \mathrm{g})$ in the liver and muscle of some food-producing animals and rats. The data represent the mean \pm SD for 20 animals from each species. Columns carrying different large character letter are significantly different with each other among liver samples, while those carrying different small character letter are significantly different among muscle samples $(P<0.05)$.

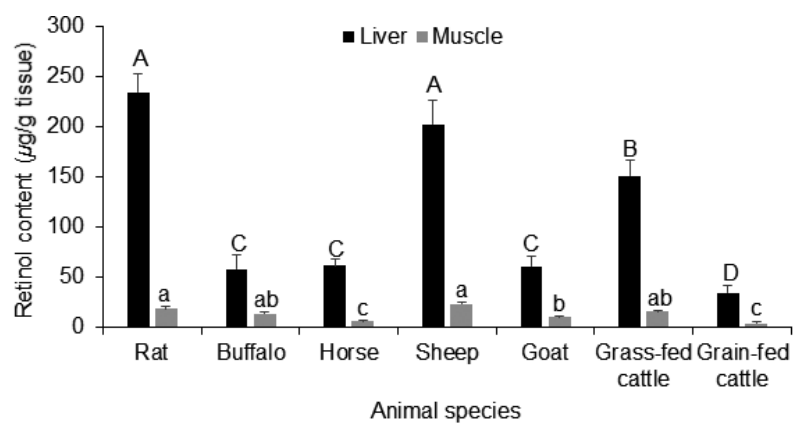

Fig. 3. Retinol content $(\mu \mathrm{g} / \mathrm{g})$ in the liver and meat of some foodproducing animals and rats. The data represent the mean $\pm \mathrm{SD}$ for 20 animals from each species. Columns carrying different large character letter are significantly different with each other among liver samples, while those carrying different small character letter are significantly different among muscle samples $(P<0.05)$.

and Argentine cattle $[5,8]$ and the differences in green feed may explain the differences in the obtained concentrations among these studies. In addition, our results go in line with the previous report of Alvarez et al. [1], who detected significantly higher concentrations of $\beta$-carotene and retinol in the fat and plasma of lambs fed on pasture than those fed on concentrate diets. Although yellow carcass fat consumption is discouraged in many countries around the world, it is also associated with a healthier fatty acid profile and a higher antioxidant content [9].

Plant-derived foods supply human with the majority of his requirements from these phytochemicals, however, the role of meat and meat products in supplying man with these requirements is scarcely investigated. The current recommended daily intake of vitamin A is 900 to $1,500 \mu \mathrm{g}$ for men and 700 to $1,200 \mu \mathrm{g}$ for women, respectively, [16]. The calculated results for the EDI of carotenoids and retinol from the ingestion of liver and muscle showed that consumption

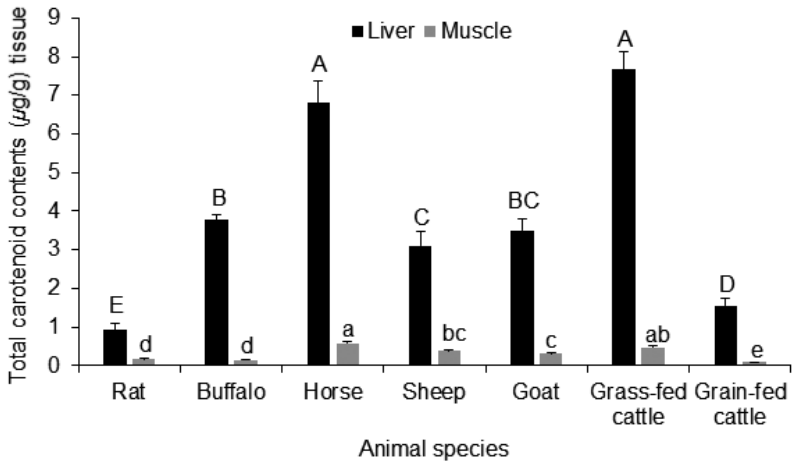

Fig. 2. Total carotenoid content $(\mu \mathrm{g} / \mathrm{g})$ in the liver and meat of some food-producing animals and rats. The data represent the mean $\pm \mathrm{SD}$ for 20 animals from each species. Columns carrying different large character letter are significantly different with each other among liver samples, while those carrying different small character letter are significantly different among muscle samples $(P<0.05)$.

of these tissues might provide human either males or females with part of his needs from the carotenoids and retinoids (Table 1). To the best of our knowledge, there is no required daily allowance for $\beta$-carotene or other pro-vitamin A carotenoids, as it is just suggested to consume $3 \mathrm{mg}$ of $\beta$-carotene daily to maintain plasma $\beta$-carotene in the range associated with normal function and a lowered risk of chronic diseases [16]. However, the intake of vitamin A (retinol) for pregnant women should not exceed $3.3 \mathrm{mg} /$ day $[12,22]$. The results in Table 1 showed that liver of all examined animals had higher concentrations of retinol than the recommended ones [22], due to the elevated concentrations of retinol in the livers, particularly that of sheep and cattle. It is advisable for the Egyptian pregnant women to reduce their intake from livers, as this may lead to increased risk of the teratogenic effects.

In conclusion, this study showed that grass fed-cattle and horse had the highest contents of total carotenoids and $\beta$-carotene followed by goat, buffalo and sheep. Unexpectedly, rat and sheep were high accumulators for retinol followed by cattle, horse, goat and buffalo, respectively. Grass-fed cattle had high contents of these phytochemicals compared with grain-fed animals. Liver had higher contents of the examined chemicals compared with meat. Consumption of these tissues may provide Egyptians with a portion of their needs from these important phytochemicals. Additionally, a future study should be considered to estimate the total carotenoids and retinoids in other animal parts like intestines, colon, spleen, brain, kidneys, hearts and lungs.

ACKNOWLEDGMENTS. This study was supported in part by the Grants-in-Aid for Scientific Research from the Japanese Society for the Promotion of Science (JSPS) to W. S. Darwish (No.23001097), M Ishizuka (No. 24248056, 24405004 and Core to Core program). W. S. Darwish is a recipient of a postdoctoral fellowship from the JSPS. 
Table 1. Estimated daily intake (mg/adult Egyptian) of $\beta$-carotene, total carotenoids and retinol due to ingestion of liver and muscle of meat-producing animals

\begin{tabular}{|c|c|c|c|c|c|c|}
\hline & \multicolumn{2}{|c|}{$\beta$-carotene } & \multicolumn{2}{|c|}{ Total carotenoids } & \multicolumn{2}{|c|}{ Retinol } \\
\hline & Liver & Muscle & Liver & Muscle & Liver & Muscle \\
\hline Buffalo & $0.31 \pm 0.009$ & $0.01 \pm 0.001$ & $0.33 \pm 0.129$ & $0.01 \pm 0.001$ & $5.09 \pm 1.231^{\mathrm{a})}$ & $1.21 \pm 0.121$ \\
\hline Cattle & $0.61 \pm 0.067$ & $0.06 \pm 0.006$ & $0.67 \pm 0.041$ & $0.04 \pm 0.001$ & $\left.13.23 \pm 1.053^{\mathrm{a}}\right)$ & $1.39 \pm 0.134$ \\
\hline Horse & $0.56 \pm 0.054$ & $0.05 \pm 0.005$ & $0.59 \pm 0.051$ & $0.05 \pm 0.001$ & $5.39 \pm 0.055^{\mathrm{a})}$ & $0.55 \pm 0.004$ \\
\hline Sheep & $0.25 \pm 0.021$ & $0.03 \pm 0.002$ & $0.27 \pm 0.033$ & $0.03 \pm 0.002$ & $17.76 \pm 2.045^{\mathrm{a})}$ & $2.04 \pm 0.103$ \\
\hline Goat & $0.28 \pm 0.023$ & $0.03 \pm 0.002$ & $0.31 \pm 0.027$ & $0.03 \pm 0.002$ & $5.34 \pm 0.941^{\mathrm{a})}$ & $0.94 \pm 0.084$ \\
\hline
\end{tabular}

The data represent the mean \pm SD for EDI (mg/adult Egyptian) of $\beta$-carotene, total carotenoids and retinol due to ingestion of liver and muscle of different meat-producing animals ( $\mathrm{n}=20$ animals from each species). Values carrying star marks indicate higher than the recommended levels by WHO (2011).

\section{REFERENCES}

1. Álvarez, R., Meléndez-Martínez, A. J., Vicario, I. M. and Alcalde, M. J. 2014. Effect of pasture and concentrate diets on concentrations of carotenoids, vitamin A and vitamin $\mathrm{E}$ in plasma and adipose tissue of lambs. J. Food Compos. Anal. 36: 59-65. [CrossRef]

2. Beauchesne-Rondeau, E., Gascon, A., Bergeron, J. and Jacques, H. 2003. Plasma lipids and lipoproteins in hypercholesterolemic men fed a lipid-lowering diet containing lean beef, lean fish, or poultry. Am. J. Clin. Nutr. 77: 587-593. [Medline]

3. Blomhoff, R., Green, M. H., Green, J. B., Berg, T. and Norum, K. R. 1991. Vitamin A metabolism: new perspectives on absorption, transport, and storage. Physiol. Rev. 71: 951-990. [Medline]

4. Chapman, M. S. 2012. Vitamin a: history, current uses, and controversies. Semin. Cutan. Med. Surg. 31: 11-16. [Medline] [CrossRef]

5. Daley, C. A., Abbott, A., Doyle, P. S., Nader, G. A. and Larson, S. 2010. A review of fatty acid profiles and antioxidant content in grass-fed and grain-fed beef. Nutr. J. 9: 10-21. [Medline] [CrossRef]

6. Darwish, W. S., Ikenaka, Y., Ohno, M., Eldaly, E. A. and Ishizuka, M. 2010. Carotenoids as regulators for inter-species difference in cytochrome P450 1A expression and activity in ungulates and rats. Food Chem. Toxicol. 48: 3201-3208. [Medline] [CrossRef]

7. Descalzo, A. M. and Sancho, A. M. 2008. A review of natural antioxidants and their effects on oxidative status, odor and quality of fresh beef produced in Argentina. Meat Sci. 79: 423-436. [Medline] [CrossRef]

8. Descalzo, A. M., Insani, E. M., Biolatto, A., Sancho, A. M., García, P. T., Pensel, N. A. and Josifovich, J. A. 2005. Influence of pasture or grain-based diets supplemented with vitamin E on antioxidant/oxidative balance of Argentine beef. Meat Sci. 70: 35-44. [Medline] [CrossRef]

9. Dunne, P. G., Monahan, F. J., O'Mara, F. P. and Moloney, A. P. 2009. Colour of bovine subcutaneous adipose tissue: A review of contributory factors, associations with carcass and meat quality and its potential utility in authentication of dietary history. Meat Sci. 81: 28-45. [Medline] [CrossRef]

10. Food and Agricultural Organization (FAO). 2003. Nutrition Country Profiles -EGYPT. FAO, Rome, Italy.

11. Hosotani, K. and Kitagawa, M. 2003. Improved simultaneous determination method of $\beta$-carotene and retinol with saponification in human serum and rat liver. J. Chromatogr. B Analyt. Technol. Biomed. Life Sci. 791: 305-313. [Medline] [CrossRef]
12. Howells, L. C. and Livesey, C. T. 1998. A survey of vitamin A concentrations in the liver of food-producing animals. Food Addit. Contam. 15: 10-18. [Medline] [CrossRef]

13. Hunninghake, D. B., Maki, K. C., Kwiterovich, P. O. Jr., Davidson, M. H., Dicklin, M. R. and Kafonek, S. D. 2000. Incorporation of lean red meat into a National Cholesterol Education Program Step I diet: a long-term, randomized clinical trial in free-living persons with hypercholesterolemia. J. Am. Coll. Nutr. 19: 351-360. [Medline] [CrossRef]

14. Larsen, M. K., Fretté, X. C., Kristensen, T., Eriksen, J., Søegaard, K. and Nielsen, J. H. 2012. Fatty acid, tocopherol and carotenoid content in herbage and milk affected by sward composition and season of grazing. J. Sci. Food Agric. 92: 2891-2898. [Medline] [CrossRef]

15. Melanson, K., Gootman, J., Myrdal, A., Kline, G. and Rippe, J. M. 2003. Weight loss and total lipid profile changes in overweight women consuming beef or chicken as the primary protein source. Nutrition 19: 409-414. [Medline] [CrossRef]

16. National Institute of Health (NIH) Clinical Nutrition Center. 2002. Facts about dietary supplements: Vitamin A and Carotenoids. Ref Type: Pamphlet.

17. Scott, L. W., Dunn, J. K., Pownall, H. J., Brauchi, D. J., McMann, M. C., Herd, J. A., Harris, K. B., Savell, J. W., Cross, H. R. and Gotto, A. M. Jr. 1994. Effects of beef and chicken consumption on plasma lipid levels in hypercholesterolemic men. Arch. Intern. Med. 154: 1261-1267. [Medline] [CrossRef]

18. Smith, D. R., Wood, R., Tseng, S. and Smith, S. B. 2002. Increased beef consumption increases apolipoprotein A-I but not serum cholesterol of mildly hypercholesterolemic men with different levels of habitual beef intake. Exp. Biol. Med. (Maywood) 227: 266-275. [Medline]

19. Yang, A., Brewster, M. J., Lanari, M. C. and Tume, R. K. 2002. Effect of vitamin E supplementation on $\alpha$-tocopherol and $\beta$-carotene concentrations in tissues from pasture- and grain-fed cattle. Meat Sci. 60: 35-40. [Medline] [CrossRef]

20. Yang, A., Larsen, T. W. and Tume, R. K. 1992. Carotenoid and retinol concentrations in serum, adipose tissue, liver, and carotenoids transport in sheep, goats and cattle. Aust. J. Agric. Res. 43: 1809-1817. [CrossRef]

21. World Health Organization (WHO). 1987. Principles for the safety assessment of food additives and contaminants in food. Environ. Health Criteria 70: http://www.inchem.org/documents/ ehc/ehc/ehc70.htm.

22. World Health Organization (WHO). 2011. Guideline: Vitamin A supplementation in pregnant women. http://apps.who.int/iris/ bitstream/10665/44625/1/9789241501781_eng.pdf. 